Rocznik Przektadoznawczy
Studia nad teoria, praktyką i dydaktyką przekładu

Maciej Pławski

Toruń

\title{
O TŁUMACZENIU JAKO CZYNNOŚCI UWARUNKOWANEJ KULTUROWO NA PRZYKŁADZIE FRAZEOLOGIZMÓW ZAWIERAJĄCYCH ETNONIMY
}

\begin{abstract}
Zarys treści: Stałe związki frazeologiczne zawierające etnonimy występują w wielu (prawdopodobnie wszystkich) językach europejskich, przypisujemy przy tym różnym narodom często cechy negatywne. Frazeologizmy jako jednostki będące składnikiem kultury wykazują w związku z tym względną nieprzekładalność, a przynajmniej mogą okazać się fałszywymi przyjaciółmi tłumacza. Celem artykułu jest ukazanie problemu tłumaczenia jako czynności uwarunkowanej kulturowo na przykładzie frazeologizmów zawierających etnonimy.
\end{abstract}

Słowa kluczowe: tłumaczenie, frazeologizm, etnonim, fałszywi przyjaciele

$\mathrm{O}$ d momentu biblijnego pomieszania języków konieczne stało się istnienie tłumaczy, jako osób, które umożliwiają kontakty międzyjęzykowe. Oczywiście tego typu definicja profesji tłumacza zawęża w znacznym stopniu jego znaczenie, jak i zakres jego działalności. Możliwe jest mianowicie oprócz tłumaczenia interlingwalnego (międzyjęzykowego) także thumaczenie intralingwalne, w ramach tego samego języka (por. Koller 1972: 11). W związku z rosnącą specjalizacją i wiążącą się z nią komplikacją tekstów fachowych ten drugi typ tłumaczenia wydaje się zyskiwać w dzisiejszym świecie na znaczeniu (jako przykład tłumaczeń intralingwalnych mogą posłużyć ulotki dołączane do leków, będące w zasadzie tłumaczeniem na język potoczny, według pewnych sformalizowanych zasad, skomplikowanych formuł farmaceutycznych). Tematem niniejszego artykułu ma jednak być tłumaczenie interlingwalne, czyli pośredniczące w komunikacji pomiędzy osobami posługującymi się różnymi ję- 
zykami. Problematykę thumaczeń postaram się przedstawić na przykładzie sformułowań zaliczanych do tzw. frazeologizmów, skupiając się przy tym na związanych z ich użyciem uwarunkowaniach kulturowych, mających wpływ na proces komunikacji w ogóle, a szczególnie wyraźnych w procesie translacji. Celem mojego artykułu jest ukazanie problemu na przykładzie wybranych frazeologizmów zawierających etnonimy w różnych językach. Studium moje nie ma jednak charakteru całościowego, chodzi raczej o zwrócenie uwagi na problem, dzięki przytoczeniu dość wyrywkowego materiału.

Wydaje się, że z tłumaczami mamy do czynienia od zarania ludzkiej historii. Już w starożytnym Egipcie mowa jest o tłumaczach „dragomanach”, którzy pełnili ważną funkcję $\mathrm{w}$ administracji, wojsku i handlu. $\mathrm{O}$ wadze tego zawodu może świadczyć fakt, że tworzyli oni obok kapłanów, wojskowych, pasterzy i innych - nawet oddzielną klasę społeczną (por. Mounin 1967: 23) Także w Biblii znajdujemy wzmianki dotyczące wykształcenia potencjalnych tłumaczy:

Król polecił [...] sprowadzić spośród Izraelitów z rodu królewskiego oraz z możnowładców młodzieńców bez jakiejkolwiek skazy, o pięknym wyglądzie, obeznanych z wszelką mądrością, posiadających wiedzę i obdarzonych rozumem, zdatnych do służby w królewskim pałacu. Zamierzał ich nauczyć pisma i języka chaldejskiego. [...] Mieli być wychowywani przez trzy lata, by po ich upływie rozpoczą́ służbę przy królu (Pismo Święte 1990: Da 1, 4-5).

O rozkwicie tej profesji możemy mówić w odniesieniu do starożytnego Rzymu, rozległość imperium i wielość występujących w nim nacji spowodowały bowiem konieczność utrzymywania armii thumaczy. Także historia literatury rzymskiej rozpoczyna się thumaczeniami (por. Koller 1972: 16n.). W tym kontekście należy nawiązać do ukutego przez Augustyna określenia medius currens, które miało oznaczać właśnie mówiącego pośrednika między ludźmi (por. Koller 1972: 14). W związku z powyższym i w nawiązaniu do niektórych definicji przytaczanych $w$ literaturze przedmiotu na proces tłumaczenia wydaje się mieć wpływ kilka czynników: Neubert określa tłumaczenie jako produkcję tekstu w języku docelowym opartą na tekście języka wyjściowego (por. Neubert 1895: 18). Ta dość krótka, acz treściwa definicja podkreśla $\mathrm{z}$ jednej strony związek translatu z tekstem wyjściowym, z drugiej strony akcentuje jego niezależność od oryginału. W pewnym sensie przekład dla czytelnika, który z definicji nie ma przeważnie kontaktu z tekstem wyjściowym, funkcjonuje jako tekst niezależny, twór ukształtowany przez tłumacza, jako pośrednika, wymienianego medius currens. Oczywiście od tego typu stwierdzeń już tylko krok do znanej włoskiej formuły traduttore - traditore, zestawiającej tłumacza ze zdrajcą, czyli kimś, kto nie umie dochować wierności oryginałowi. Ucząc się, nauczając języ- 
ka obcego i w końcu także thumacząc, często natrafiamy na treści, które są w pewnym stopniu nieprzekładalne. Musimy bowiem często wybierać między wiernością oryginałowi a umożliwieniem zrozumienia go przez adresata. Przy thumaczeniu uwzględnić powinniśmy dwojaką perspektywę:

- top-down - zależność tekstu od uwarunkowań pozajęzykowych języka tekstu oryginału i translatu,

- bottom-up - użycie adekwatnych i ekwiwalentnych znaków oraz ich kombinacji systemu języka źródłowego i docelowego (por. Neubert 1990: 32n.).

W odniesieniu do perspektywy top-down szczególną rolę odgrywają uwarunkowania kulturowe charakterystyczne dla danej wspólnoty językowej. Snell-Hornby definiuje w związku z powyższym thumaczenie jako cross-cultural event (Snell-Hornby 1988: 39); także w innych źródłach znajdujemy definicje odwołujące się do czynników kulturowych. Risku (1998: 14n.) w swoim modelu podkreśla następujące kognitywne podstawy tłumaczenia:

- kontekst (inter)kulturalny i komunikacyjny,

- całościowy proces thumaczenia z uwzględnieniem rodzaju zlecenia, omówieniem sposobu rozwiązywania problemów przekładu i optymalizacji jego wyników uzależnionej od odbiorcy,

- rozwój sprawności koniecznych do thumaczenia.

Z powyższego zestawienia wynika jednoznacznie, jak wielkie znaczenie dla przekładu mają treści kulturowe. We współczesnej literaturze przedmiotu coraz częściej odchodzi się od ujęcia thumaczenia jako prostego procesu transkrypcji, thumaczenia interlinearnego (por. Nord 1995: 33), a coraz częściej podkreśla się rolę thumaczenia jako działalności umożliwiającej komunikację pomimo różnic kulturowych.

Każdy $\mathrm{z}$ nas niewątpliwie doświadczył różnic $\mathrm{w}$ zwyczajach istniejących między użytkownikami różnych języków wywodzących się nawet $\mathrm{z}$ tego samego kręgu kulturowego ${ }^{1}$. Im kultury okazują się bardziej różne, tym większe jest znaczenie czynników kulturowych dla procesu translacji. W wyemitowanym niedawno przez TVP 1 hinduskim filmie „Monsunowe wesele” mogliśmy usłyszeć stwierdzenie ojca panny młodej odnoszące się do namiotu weselnego, które brzmiało następująco: „Dlaczego on jest biały, czy ja zapraszam ludzi na pogrzeb?". Stwierdzenie to może być zrozumiane jedynie w kontekście kultury wschodnioazjatyckiej, w której kolor biały jest kolorem żałoby. Tym ważniejsze wydaje się sformułowanie Willsa (1977: 120) mówiące, że tłumacz musi dysponować:

${ }^{1}$ Wystarczy pójść na spacer w Niemczech, by tego doświadczyć, bo mijający się nieznajomi pozdrawiają się przyjaźnie. 
a) kompetencją receptywną w języku źródłowym,

b) kompetencją produktywną w języku docelowym,

c) superkompetencją pozwalającą przetransformować informacje pomiędzy systemem językowym i tekstowym kultury źródłowej a językowym i tekstowym systemem kultury docelowej.

W kontekście stwierdzeń Willsa podkreślenie roli czynników kulturowych w procesie przekładu wydaje się jak najbardziej zasadne. Kultura wytwarza wokół człowieka sferę społeczną umożliwiającą życie socjalne. Dla pełnienia tej funkcji konieczne jest jednak urządzenie umożliwiające przechowywanie i przekazywanie doświadczenia ludzkiego. Tym urządzeniem jest język (por. Łotman, Uspieński 1977: 150).

Oczywiście przykłady uwarunkowania thumaczenia przez czynniki kulturowe można by było mnożyć, w niniejszym tekście chciałbym przytoczyć tylko jeden przykład odnoszący się do tłumaczenia modlitwy Ojcze nasz na język eskimoski. W przekładzie zaszła potrzeba zastąpienia fragmentu „chleba naszego powszedniego" zwrotem ,ryby naszej powszedniej”, język eskimoski nie posiada bowiem terminu „chleb”, a „chleb” w tym kontekście nie oznacza konkretnego środka spożywczego wyrabianego z mąki, lecz najpospolitszy i najpowszechniejszy środek spożywczy. Dla Eskimosów takim typem pożywienia jest właśnie ryba (por. Wojtasiewicz 1996: 20).

Z powyższych wywodów wynika, że istnieją bardzo silne związki między kulturą a językiem. Język jest bowiem nie tylko produktem kultury, ale także przede wszystkim jej nośnikiem. W społeczności ludzkiej rządzą różne normy, są one po części skodyfikowane (normy prawne, religijne), inne wiążą się $\mathrm{z}$ tradycją i zawarte są w tzw. pamięci zbiorowej (por. Czochralski 2004: 349). Oczywiście normy społeczne są różne w różnych wspólnotach językowych, różnice występują nawet pomiędzy poszczególnymi grupami społecznymi w ramach jednej wspólnoty (mogą istnieć także różnice między użytkownikami tego samego języka: Wielka Brytania a Stany Zjednoczone Ameryki Północ$n^{2}{ }^{2}$, RFN, Austria a Szwajcaria). Różnice te znajdują odzwierciedlenie w języ$\mathrm{ku}, \mathrm{w}$ jego użyciu, ale także w poszczególnych jednostkach. Frazeologizmy jako jednostki o stosunkowo stabilnej formie są szczególnie podatne na uwarunkowania kulturowe. Normy, symbole, zwyczaje, stereotypy, uprzedzenia charakterystyczne dla danej społeczności bardzo często znajdują w nich swe

\footnotetext{
${ }^{2}$ Nie chcę w tym miejscu rozwijać dyskusji, czy w odniesieniu do nazwanych powyżej państw możemy mówić o tym samym języku, czy też raczej należałoby rozróżnić np. język angielski i amerykański.
} 
odzwierciedlenie ${ }^{3}$. Frazeologizmy są jednostkami definiowanymi w literaturze przedmiotu w sposób dość różnorodny ${ }^{4}$, w związku z powyższym - odwołując się do teorii prototypu, chciałbym zaliczyć do tej kategorii formacje następującego typu:

kopnać w kalendarz, kick the bucket, den Löffel abgeben, siedzieć jak na tureckim kazaniu, jemandem eine Falle stellen

W niniejszej analizie chciałbym zająć się frazeologizmami zawierającymi etnonimy, czyli nazwy narodowości, narodów, plemion lub określeń od nich pochodnych. Etnonimy odsyłając do określonej grupy narodowej, obarczone są często dużym ładunkiem emocjonalnym, konotując określone cechy lub atrybuty przypisywane danemu narodowi przez daną wspólnotę językową. W odniesieniu do tego typu wyobrażeń utrwalonych w języku, dostępnych przez język i przynależnych do wspólnotowej wiedzy o świecie możemy mówić o stereotypach (por. Bartmiński 1996: 9). Istnieją oczywiście także ponadnarodowe stereotypy językowo-kulturowe, dotyczące np. skąpstwa Szkotów i precyzji Szwajcarów (por. Pisarkowa 1976), które nie stanowią specjalnego problemu translacyjnego. Jednak większość stereotypowych etnonimów rzadko przekracza granice językowe, utrudniając pracę thumaczom. W przypadku określeń etnicznych zawartych we frazeologizmach zadanie to okazuje się podwójnie trudne, wyrażenia frazeologiczne są bowiem elementem zasobu leksykologicznego języka, który szczególnie mocno utrwala kulturę społeczności posługującej się nim (por. Zalewski 2003: 331). Na ten problem nakłada się problem funkcjonowania etnonimów jako nazw nienarodowych, związanych często ze stereotypowym widzeniem świata. W niniejszym artykule chciałbym podać kilka przykładów zaczerpniętych z różnych języków, które mogą okazać się problemem translatorskim. Chodzi tu raczej o dość wybiórczo przytoczone przykłady, a nie dogłębną analizę problemu. W odniesieniu do badanych frazeologizmów zawierających etnonimy można stwierdzić, że określenia narodowości pełnią w tekstach trzy funkcje (Nycz 2002: 171):

1) referencyjną - jest to nazwa własna odnosząca się do określonego narodu lub jego przedstawiciela,

2) stereotypową - nazwa pospolita wiążąca się z cechami przypisywanymi określonemu narodowi, bazującymi na uprzedzeniach odnoszących się do innych narodów (Sandig 1994: 91),

\footnotetext{
${ }^{3}$ Więcej na temat symboli występujących we frazeologizmach w Dobrovol'skij, Piirainen 1997, na temat symboli we frazeologizmach i problemów związanych z ich tłumaczeniem w Pławski $2005^{1}$.

${ }^{4}$ Więcej na temat problemów związanych z definiowaniem frazeologizmów i prób określenia tej grupy formacji w Pławski $2005^{2}$.
} 
3) nienarodową - referentem jest nie naród, lecz rzeczy i zjawiska, ich związek z danym narodem jest jedynie kwestią etymologii.

W badanych frazeologizmach chciałbym się skupić jedynie na przypadkach, gdy etnonimy pełnią dwie ostatnie funkcje. Jako baza porównawcza służą przykłady z języków: angielskiego, francuskiego, hiszpańskiego, niemieckiego i polskiego, analiza nie stanowi jednak wyczerpującego studium problemu, chodzi jedynie o ukazanie na dość wybiórczo dobranych przykładach pewnych różnic i podobieństw, będących potencjalną przyczyną problemów translacyjnych; w odniesieniu do niektórych języków przytoczę także przykłady niebędące frazeologizmami, związane jednak z etnonimami.

Do grupy frazeologizmów zawierających etnonimy w funkcji nienarodowej można zaliczyć np.:

klucz francuski, czy może klucz angielski

Jest to „klucz nastawny o regulowanej odległości szczęk, służący do odkręcania i dokręcania nakrętek i śrub" (PWN 2004). W języku polskim, niemieckim i angielskim znajdujemy określenie klucz francuski, Franzose (Duden 2003), wrench (Cambridge 2003) - oczywiście w odniesieniu do języka niemieckiego i angielskiego nie mamy tu do czynienia z frazeologizmami - natomiast $\mathrm{w}$ języku francuskim, hiszpańskim i niemieckim używa się na tego typu narzędzia także określenia klucz angielski: 'clé anglaise, la llave inglesa (Nycz 2002: 175), Engländer ${ }^{5}$ (Komenda 2003: 10).

Drugą grupę stanowią frazeologizmy $\mathrm{z}$ etnonimami w funkcji stereotypowej, opisujące cechy przypisywane danej narodowości:

pożegnać się po francusku czy może wyjść po angielsku

$\mathrm{W}$ języku polskim mamy do czynienia z wyrażeniem wyjść, wymknać się itp. po angielsku w znaczeniu „wyjść bez pożegnania, niepostrzeżenie” (PWN 2004), także w języku francuskim i niemieckim występują frazy filer à l'anglaise (Nycz 2002: 174), sich (auf) englisch empfehlen (Duden 2003), odnoszące się do Anglików. $Z$ drugiej strony mamy jednak w języku angielskim, hiszpańskim i niemieckim podobne frazy odnoszące się do Francuzów: to take French leave (to leave yuor job without permission (Longmann 2000)), marcharse a la francesa ( $\mathrm{Nycz}$ 2002, 174), sich (auf) französisch empfehlen/verabschieden/ (auf) französisch Abschied nehmen (Komenda 2003: 111). W odniesieniu do opisywanej czynności znajdujemy także określenia nawiązujące do Hiszpanów: despedirse a la espanola (Nycz 2002: 174).

francuska, niemiecka czy może polska choroba

\footnotetext{
${ }^{5}$ Oczywiście w odniesieniu do języka niemieckiego nie mamy do czynienia $\mathrm{z}$ frazeologizmem.
} 
W języku polskim odnajdujemy określenie francuska choroba - jest to „choroba weneryczna; kiła” (PWN 2004), także w języku angielskim, hiszpańskim i niemieckim, znajdujemy określenie, french illness, enfermedad francesa (http://www.bvs.sld.cu/ revistas / hie/ vol42_2_04 /hig08204.htm), französisch krank sein/Franzosenkrankheit (Komenda 2003: 109-111). W języku polskim istnieje jednak także zwrot niemiecka choroba (http://kiosk.onet.pl/art.html? $\mathrm{DB}=162 \& \mathrm{ITEM}=1011879$ ), a w rosyjskim występuje określenie 'polska' choroba Польская болезнь (http://www.infospid.ru/popular/ippp/syphilis/).

być pijanym jak Rusek, Polak czy też może Irlandczyk

$\mathrm{W}$ języku niemieckim i francuskim znajdujemy porównania jemand ist voll wie ein Pole, qn. est soûl comme un Polonais bazujące na stereotypie „Polacy piją dużo". W niemieckim używa się także frazy jemand ist betrunken wie ein Russe (Eismann 1994: 95), podczas gdy w rosyjskim przesadne użycie alkoholu przypisywane jest Szwedom (Eismann 1994: 95), a w angielskim Irlandczykom drunk as an Irish (http://planetpotato.blogs.com/planet_potato_an_irish_bl/ 2005/04/doing_business.html).

Jak wynika z powyższego, dość wyrywkowego zestawienia, etnonimy występujące w związkach stałych nawiązują często do stereotypów odnoszących się do sąsiadów. Czasami okazują się one prawdziwymi przyjaciółmi tłumacza, występują bowiem w podobnej formie w kilku językach. Wiele przykładów ukazuje jednak, że często w różnych językach w podobnych lub tych samych frazach występują inne etnonimy, co może stanowić trudność w ich thumaczeniu, tym bardziej że zjawiska wykazujące niewielkie różnice są bardziej podatne na interferencję międzyjęzykową. Etnonimy używane w stałych związkach są niewątpliwym elementem stereotypowej wiedzy danego narodu, a jako element kultury mogą stanowić pewien problem translacyjny.

\section{Literatura}

Bartmiński, J. 1996, Stereotyp jako przedmiot lingwistyki, [w:] Z problemów frazeologii polskiej i stowiańskiej, red. M. Basaj, T. Rytel, t. 4, Lublin, s. $25-53$.

Cambridge 2003, Version 1.0, University Press.

Czochralski, J. 2004, Faktoren, die die interkulturelle Verständigung erschweren, [w:] Sprachwissen in der Hochschulgermanistik. Interkulturelle Kom- 
munikation. Referate von den Konferenzen in Karpacz 2001, in Stubice 2002, red. U. Engel, s. 349-353.

Dobrovol'skij, D. O., Piirainen, E. 1997, Symbole in Sprache und Kultur: Studien zur Phraseologie aus kultursemiotischer Perspektive, Studien zur Phraseologie und Parömiologie 8, Bochum.

Duden 2003, Die CD-ROM basiert auf der 5., neu bearbeiteten und erweiterten Auflage der Buchausgabe - 2003, Bibliographisches Institut \& N. A. Brockhaus AG, Mannheim 2003

Eismann, W. 1994, Nationales Stereotyp und sprachliches Klischee. Deutsche und Slawen im Lichte ihrer Phraseologie und Parömiologie, [w:] Europhras 92. Tendenzen der Phraseologieforschung, red. B. Sandig, Studien zur Phraseologie und Parömiologie 1, Bochum, s. 81-107.

Koller, W. 1972, Grundprobleme der Übersetzungstheorie. Unter besonderer Berücksichtigung schwedisch-deutscher Übersetzungsfälle, Bern-München.

Komenda, B. 2003, Sekundäre Bedeutungen von Nationalitäts- und Länderbezeichnungen im Deutschen und Polnischen. Unter besonderer Berücksichtigung der semantischen Gebrauchstheorie, [w:] Danziger Beiträge zur Germanistik, red. A. Kątny, t. 9, Frankfurt am Main.

Longman 2000, Longman Dictionary of Contemporary English ( $3^{\text {rd }}$ Edition), Pearson Education Limited, Software developed by Opti Média Paris.

Łotman, J., Uspieński, B. 1977, O semiotycznym mechanizmie kultury, [w:] Semiotyka kultury, red. E. Janus, M. R. Mayenowa, Warszawa, s. 147-170.

Mounin, G. 1967, Die Übersetzung. Geschichte, Theorie, Anwendung, München.

Neubert, A. 1985, Text und Translation, Übersetzungswissenschaftliche Beiträge 8 , Lipsk.

Neubert, A. 1990, Übersetzen als „Aufhebung“ des Ausgangstextes, [w:] Übersetzungswissenschaft. Ergebnisse und Perspektiven: Festschrift für Wolfram Wills zum 65. Geburtstag, red. R. Arntz, Tübinger Beiträge zur Linguistik 354, Tübingen, s. 31-39.

Nord, Ch. 1995, Textanalyse und Übersetzen:theoretische Grundlagen, Methode und didaktische Anwendung einer übersetzungsrelevanten Textanalyse, Heidelberg.

Nycz, M. 2002, Etnonimia - stereotyp - przekład, [w:] Język stereotyp prze$k ł a d$, red. E. Skibińska, M. Cieński, Dolośląskie Wydawnictwo Edukacyjne, Wrocław, s. 169-177.

Pisarkowa, K. 1976, Konotacje semantyczne nazw narodowości, Zeszyty Prasoznawcze, XVII/1, s. 5-26. 
Pismo Święte Starego i Nowego Testamentu w przektadzie z języków oryginalnych. Biblia Tysiaclecia, Wydanie trzecie poprawione (1990), Wydawnictwo Pallottinum, Poznań-Warszawa.

Pławski, M. 2005', Czy tlumaczenia musza być tak, jak kobiety (i mężczyźni) wierne - kilka uwag o (nie)przettumaczalności, [w:] Kulturowe i językowe źródła nieprzektadalności, Materiały z konferencji naukowej zorganizowanej przez Wydziat Filologiczny Wszechnicy Mazurskiej w Olecku w dniach 31 maja i 1 czerwca 2004 r., Studia Językoznawcze Wszechnicy Mazurskiej, red. K. Hejwowski, Olecko, s. 235-244.

Pławski, M. 2005², Zu einigen Aspekten der Phraseologieforschung aus kognitiver Sicht, Zeszyty Naukowe Wyższej Szkoły Biznesu w Pile, Seria Filologia, Filologia Germańska 1, red. J. Grabarek, t. 1, Piła, s. 123-132.

PWN - Słownik języka polskiego PWN (2004). Wersja 1.0, Wydawnictwo Naukowe PWN SA.

Risku, H. 1998, Translatorische Kompetenz: kognitive Grundlagen des Übersetzens als Expertentätigkeit, Studien zur Translation 5, Tübingen.

Snell-Hornby, M. 1988, Translation Studies. An Integrated Approach, Amsterdam/Filadelfia.

Wills, W. 1977, Übersetzungswissenschaft. Probleme und Methoden, Stuttgart.

Wojtasiewicz, O. A. 1996, Wstęp do teorii tlumaczenia, Warszawa.

Zalewski, R. 2003, Ttumacz wobec frazeologicznych porównań kolorystycznych, [w:] Między oryginatem a przektadem. Stereotyp a przektad, red. U. Kropiwiec, M. Filipowicz-Rudek, J. Konieczna-Twardzikowa, Kraków, s. 331-342.

Internet:

http://kiosk.onet.pl/art.html?DB=162\&ITEM=1011879

http://planetpotato.blogs.com/planet_potato_an_irish_bl/2005/04/

doing_business_html

http://www.bvs.sld.cu/revistas/hie/vol42_2_04/hig08204.htm

http://www.infospid.ru/popular/ippp/syphilis/ 


\section{Some comments on translating as a culturally contingent ac- tion on the example of idioms with ethnic labels}

\section{Summary}

It has always been clear to any participant of any communicative situation that there is a need for the translator and interpreter. This need for translation activities has also been found in the Bible. Translations played also an important role in Greek and Latin literature or culture. In each language we may find numerous ethnic labels that apart from presenting the meaning representative for a particular nation, also fulfill certain other functions. We frequently impute to other people certain forms of behaviour that may be evaluated as prejudices. The translation of such lexical units is especially difficult because they tend to be semantically different in various languages. In this article the author aims at the discussion of problems connected with the translation of idioms with ethnic labels in different European languages.

Keywords: translation, idiom, ethnic label, false friends 